\title{
Analysis Of Factors Affecting the Quality of Audit Results at the Bengkulu Province Inspectorate Office
}

\section{Analisis Faktor-Faktor yang Mempengaruhi Kualitas Hasil Audit pada Inspektorat Provinsi Bengkulu}

\author{
Seftya Dwi Shinta \\ Fakultas Ekonomi dan Bisnis, Universitas Prof. Dr. Hazairin, SH Bengkulu \\ Email: seftyashinta01.ss@gmail.com
}

\begin{abstract}
How to Cite
Shinta, S. D. (2022). Analysis of factors affecting the quality of audit results at the Bengkulu Province Inspectorate office. Jurnal Ekonomi Manajemen Akuntansi Dan Keuangan, 3(1). DOI: https://doi.org/10.53697/emak.v3i1

ARTICLE HISTORY

Received [30 Desember 2021]

Revised [07 Januari 2022]

Accepted [27 Januari 2022]

\section{KEYWORDS}

Analysis of Factors Affecting,

Quality of Audit Results,

Bengkulu Province

Inspectorate Office

This is an open access article under the CC-BY-SA license

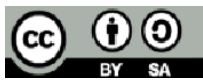

\section{ABSTRAK}

Penelitian ini bertujuan untuk menganalisis pengaruh independensi, obyektivitas, integritas, kompetensi pengalaman kerja, dan etika audit terhadap kualitas hasil audit DI Inspektorat Provinsi Bengkulu. Populasi penelitian ini adalah auditor pada Inspektorat Provinsi Bengkulu. Pengumpulan data penelitian menggunakan kuesioner. Pengambilan sampel menggunakan porposive sampling dan jumlah sampel 30 responden. Hasil penelitian ini menunjukkan bahwa obyektivitas, kompetensi , integritas, pengalaman kerja dan etika audit berpengaruh positif terhadap kualitas hasil audit internal, sedangkan independensi berpengaruh negatif terhadap kualitas hasil audit di Inspektorat Provinsi Bengkulu.

\section{ABSTRACT}

The data used was primary data with auditors working in the provincial and municipal inspectorates in Bengkulua as the respondents. The sampling technique used the purposive sampling method with 30 respondents. The results showed that objectivity, integrity, work experience, competency, and ethics of auditor's positively and significantly influenced the quality of audit results. While the variables of independency negative and significantly influenced the quality of audit results.
\end{abstract}

\section{PENDAHULUAN}

Kualitas audit merupakan salah satu hal yang penting sebagai dasar pengambilan keputusan karena kualitas audit yang tinggi akan menghasilkan laporan keuangan yang dapat dipercaya. Laporan keuangan dan audit memiliki hubungan yang erat dikarenakan audit berfungsi memberikan pendapat yang independen terhadap laporan keuangan, apakah laporan keuangan suatu entitas atau organisasi menyajikan opini yang wajar dan apakah informasi keuangan tersebut disajikan dalam bentuk yang sesuai dengan kriteria atau aturan-aturan yang telah ditetapkan sehingga menjamin akuntabilitas dan integritas dari laporan keuangan (Hardiningsih, 2010).

Dalam pengambilan keputusan pekerjaannya, auditor harus dapat mengumpulkan setiap informasi secara detail dan lengkap sesuai fakta yang ditemukan dimana hal ini didukung dengan sikap independen dan obyektif. Auditor dalam fungsi pemeriksaan (audit) memiliki peran yang sangat penting. Mulyono (2009) menjelaskan, kinerja Inspektorat merupakan kualitas dan kuantitas dari suatu hasil kerja (output) individu maupun kelompok dalam suatu aktivitas tertentu yang 
diakibatkan oleh kemampuan alami atau kemampuan yang diperoleh dari proses belajar serta keinginan untuk berprestasi lebih baik.

Dalam pengambilan keputusan pekerjaannya, auditor harus dapat mengumpulkan setiap informasi secara detail dan lengkap sesuai fakta yang ditemukan dimana hal ini didukung dengan sikap independen dan obyektif. Independen berarti auditor tidak mudah dipengaruhi dan tidak dibenarkan memihak kepentingan siapapun serta tidak akan terpengaruh dan tidak dipengaruhi oleh berbagai kekuatan yang berasal dari luar diri auditor.

Alim,dkk (2007) menyatakan bahwa kerjasama dengan objektif pemeriksaan yang terlalu lama dan berulang bisa menimbulkan kerawanan atas independensi yang dimiliki auditor. Belum lagi berbagai fasilitas yang disediakan objektif pemeriksaan selama penugasan dapat mempengaruhi objektifitas auditor, serta bukan tidak mungkin auditor menjadi tidak jujur dalam mengungkapkan fakta yang menunjukkan rendahnya integritas auditor.

Faktor lain berpengaruh terhadap kualitas hasil audit yaitu integritas. Integritas dapat menerima kesalahan yang tidak disengaja dan perbedaan pendapatan yang jujur, tetapi tidak menerima kecurangan prinsip. Teori sikap dan perilaku dapat mempengaruhi seorang tersebut untuk bertindak, jujur, adil, tegas tanpa dipengaruhi tekanan maupun permintaan dari pihak tertentu atau kepentingan pribadi yang nantinya akan perilaku auditor dapat mempengaruhi keahlian, indepensi dan etika auditor dalam mengambil judgment yang lebih berkualitas. Auditor harus memiliki kompetensi baik pendidikan, pengetahuan dan pengalaman kerja.

Pengalaman Kerja, Kompetensi dan Independensi yang dimiliki auditor sangat berkaitan dengan etika. Auditor mempunyai kewajiban untuk menjunjung tinggi standar perilaku etis mereka terhadap organisasi di mana mereka bernaung, profesi mereka, masyarakat dan diri mereka sendiri. Selain beberapa faktor tersebut, faktor etika audit juga berpengaruh erhadap kualitas hasil audit. Etika menjadi penting sebagai perilaku pribadi dalam menjalankan profesionalisme setiap tindakan.

\section{LANDASAN TEORI}

\section{Teori Atribusi}

Atribusi adalah proses menyimpulkan motif, maksud dan karakteristik orang lain dengan melihat prilakunya yang tampak (Rakhmat, 2012). Teori atribusi merupakan teori yang menjelaskan tentang perilaku seseorang. Teori atribusi menjelaskan mengenai proses bagaimana kita menentukan penyebab dan motif tentang perilaku seseorang. Hubungan teori atribusi dengan penelitian ini yaitu variabel independensi yang merupakan suatu posisi dimana kita tidak terikat dengan pihak manapun.

\section{Teori Sikap dan Perilaku}

Teori sikap dan perilaku yang di kembangkan oleh Triandis (1980) dipandang sebagai teori yang dapat mendasari untuk menjelaskan keahlian, independensi, etika dan kualitas audit. Teori tersebut menyatakan, bahwa perilaku ditentukan oleh sikap, aturan-aturan sosial dan kebiasaan.

\section{Kualitas Audit}

Audit merupakan suatu proses yang sistematik untuk memperoleh dan mengevaluasi bukti secara objektif yang dikumpulkan atas pernyataan-pernyataan mengenai kegiatan dan kejadian ekonomi, yang bertujuan untuk menetapkan tingkat kesesuaian antara pernyataan-pernyataan tersebut terhadap kriteria yang telah ditetapkan, dan serta menyampaikan kepada pihak yang berkepentingan (Agoes, 2012). Auditor dalam proses mengaudit laporan memiliki peran penting, dimana laporan hasil audit tersebut output dari proses audit. Laporan hasil audit berupa dokumendokumen yang diberikan kepada pihak berkepentingan dalam organisasi audit.

\section{Independensi}

Jurnal Ekonomi, Manajemen, Akuntansi dan Keuangan, Vol. 3 No. 1 JANUARI 2022 page: 300-305| 301 
Independensi merupakan sikap mental yang bebas dari pengaruh, tidak dikendalikan oleh pihak lain, tidak tergantung pada orang lain. Independensi dapat diartikan sebagai kejujuran dalam diri auditor dalam mempertimbangkan fakta danadanya pertimbangan yang objektif serta tidak memihak dalam merumuskan dan menyatakan pendapatnya (Mulyadi, 2014).

$\mathrm{H} 1$ : Independensi berpengaruh positif terhadap kualitas hasil audit.

\section{Obyektivitas}

Objektvitas adalah suatu keyakinan, kualitas yang memberikan nilai bagi jasa atau pelayanan auditor. Objektvitas merupakan salah satu ciri yang membedakan profesi akuntan dengan H2: Objektvitas berpengaruh positif terhadap kualitas hasil audit.

\section{Integritas}

Integritas mengharuskan seorang auditor untuk bersikap jujur dan transparan, berani, bijaksana dan bertanggung jawab dalam melaksanakan audit. Dari ke empat unsur tersebut diperlukan untuk membagun kepercayaan dan memberikan dasar bagi pengambilan keputusan yang andal. Integritas dapat menerima kesalahan yang tidak disengaja dan perbedaan pendapat yang jujur, tetapi dapat menerima kecurangan atau peniadaan prinsip (Mulyadi, 2014).

H3: Integritas berpengaruh positif terhadap kualitas hasil audit.

\section{Kompetensi}

Kompetensi auditor adalah kualifikasi yang dibutuhkan oleh auditor untuk melaksanakan audit dengan benar (Rai, 2008 dalam Sukriah, dkk 2009). Seorang auditor harus memiliki mutu personal yang baik, pengetahuan yang memadai, serta keahlian khusus di bidangnya. Standar umum pertama (SA seksi 210 dalam SPAP 2001) menyebutkan bahwa audit harus dilaksanakan oleh seorang atau lebih yang memiliki keahlian dan pelatihan teknis yang cukup sebagai auditor kompetensi berkaitan dengan keahlian profesional yang dimiliki oleh auditor sebagai hasil dari pendidikan formal, ujian profesional maupun keikutsertaan dalam pelatihan, seminar, simposium (Suraida, 2005).

H4: Kompetensi berpengaruh positif terhadap kualitas hasil audit.

\section{Pengalaman Kerja}

Pengalaman Kerja menurut SPAP (2001), dalam standar umum pertama PSA no 4, yaitu dalam melaksanakan audit untuk sampai pada suatu pernyataan pendapat, auditor harus senantiasa bertindak sebagai seorang ahli dalam bidang akuntansi dan bidang auditing. Pencapaian keahlian tersebut dimulai dengan pendidikan formalnya, yang diperluas melalui pengalamanpengalaman selanjutnya dalam praktik audit. Pengalaman Kerja auditor adalah pengalaman yang dimiliki auditor dalam melakukan audit yang dilihat dari segi lamanya bekerja sebagai auditor dan banyaknya tugas pemeriksaan yang telah dilakukan.

H5 : Pengalaman kerja berpengaruh positif terhadap kualitas hasil audit

\section{Etika Audit}

Prinsip Etika memberikan kerangka dasar bagi Aturan Etika yang mengatur pelaksanaan pemberi jasa profesional oleh anggota. Prinsip Etika disahkan oleh Kongres dan berlaku bagi seluruh anggota, sedangkan Aturan Etika disahkan oleh Rapat Anggota Himpunan dan hanya mengikat Anggota Himpunan yan bersangkutan. Interpretasi Aturan Etika merupakan interpretasi yang dikeluarkan oleh Badan yang dibentuk oleh Himpunan yang telah memperhatikan tanggapan dari anggota, dan pihak-pihak berkepentingan lainnya, sebagai panduan dalam penerapan AturanEtika, tanpa dimaksudkan untuk membatasi lingkup dan penerapannya.

H6 : Etika Audit berpengaruh positif terhadap kualitas hasil audit internal.

\section{METODE PENELITIAN}




\section{Metode Analisis Data}

Persamaan regresi linear berganda untuk masing-masing hipotesis adalah sebagai berikut:

$K A=\alpha+\beta_{1} I A+\beta_{2} O A+\beta_{3} \ln A+\beta_{4} K A+\beta_{5} P K+\beta_{6} E A+€$

Keterangan :

$\begin{array}{ll}\mathrm{KA} & =\text { Kualitas Hasil audit } \\ \mathrm{a} & =\text { Konstanta } \\ \mathrm{IA} & =\text { Independensi Auditor } \\ \mathrm{OA} & =\text { Objektifitas Auditor } \\ \mathrm{InA} & =\text { Integritas Auditor } \\ \mathrm{KA} & =\text { Kompetensi Auditor } \\ \mathrm{PK} & =\text { Pengalaman Kerja } \\ \mathrm{EA} & =\text { Etika Auditor } \\ € & =\text { eror }\end{array}$

HASIL DAN PEMBAHASAN

Hasil Uji Hipotesis

Tabel 1. Variabel Dependen Kualitas Hasil Audit

\begin{tabular}{|l|l|l|}
\hline \multicolumn{1}{c|}{ Variabel } & \multicolumn{1}{c|}{$\begin{array}{c}\text { Koefisien } \\
\text { Regresi }\end{array}$} & \multicolumn{1}{c|}{ Sig } \\
\hline Konstanta & $-8,356$ & 0,070 \\
\hline Independensi & 0,109 & 0,024 \\
\hline Objektivitas & 0,294 & 0,001 \\
\hline Integritas & 0,079 & 0,017 \\
\hline Kompetensi & 0,083 & 0,025 \\
\hline Pengalaman Kerja & 0,765 & 0,000 \\
\hline Etika Audit & 0,076 & 0,005 \\
\hline R Square & & 0,864 \\
\hline Adjusted R Square & & 0,829 \\
\hline$F$ & & 24,447 \\
\hline Sig & & 0,000 \\
\hline
\end{tabular}

Sumber: Data Primer, diolah 2020

Dapat dilihat pada tabel 4.1 di atas nilai $F=24,447$ dan nilai $p=0,000$, hal ini menunjukkan bahwa model pada penelitian ini fit, karena nilai $p<0,005$. Adjusted $R$ Square $=0,864$ atau $86,4 \%$, ini menjelaskan bahwa pengaruh semua variabel independen terhadap kualitas hasil audit adalah sebesar $86,4 \%$ atau leb dari 50\%, sedangkan sisanya 13,6\% dipengaruh oleh faktor lain di luar variabel.

\section{Pembahasan}

Pengaruh Independensi Auditor Terhadap Kualitas Audit

Berdasarkan hasil penelitian menunjukkan bahwa independens berpengaruh negatif terhadap kualitas hasil audit. Hasil uji statastik t pada variabel independensi tingkat signifikan sebesar 0,024 yang berada dibawah atau lebih kecil dari nilai $a=0,05$ maka hipotesis diterima. Hasil ini menunjukan bahwa tingkat independensi auditor di Inspektorat Provinsi Bengkulu termasuk dalam kategori tinggi Dapat ditarik kesimpulan bahwa independensi berpengaruh positif terhadap kualitas hasil audit atau dengan kata lain hipotesis pertama diterima.

\section{Pengaruh Objektivitas Auditor Terhadap Kualitas Audit}


Berdasarkan hasil penelitian menunjukan bahwa objektifitas berpengaruh terhadap kualitas hasil audit. Hasil pengujian hipotesis menunjukan bahwa variabel objektivitas auditor memiliki nilai signifikansi sebesar 0,001 yang berada dibawah atau lebih kecil dari nilai $a=0,05$ dengan nilai koefisien regresi sebesar 0,294 yang berarti bahwa Ha3 diterima dan H03 ditolak. Independensi berpengaruh terhadap kualitas hasil audit atau dengan kata lain hipotesis kedua diterima.

\section{Pengaruh Integritas Auditor Terhadap Kualitas Audit}

Berdasarkan hasil penelitian menunjukkan bahwa integritas berpengaruh signifikan terhadap kualitas hasil audit di Inspektorat Provinsi Bengkulu. Hasil uji statistik t pada variabel integritas memiliki nilai signifikan sebesar 0,017 yang berada dibawah atau lebih kecil dari nilai $\alpha=$ 0,05 dengan nilai koefisien regresi sebesar 0,079 yang artinya bahwa $\mathrm{Ha}$ diterima dan $\mathrm{Ho}$ ditolak. Berdasarkan hasil statistik deskriptif rata-rata aktual variabel integritas lebih besar dibandingkan dengan rata-rata teoitis yaitu 48,40 berbanding 39 . Hasil tersebut menunjukan bahwa auditor di Inspektorat Provinsi Bengkulu memiliki integritas sudah baik dalam melakukan audit. independensi berpengaruh terhadap kualitas hasil audit atau dengan kata lain H3 diterima.

\section{Pengaruh Kompetensi Kerja Terhadap Kualitas Hasil Audit}

Berdasarkan hasil penelitian menunjukkan bahwa kompetensi berpengaruh signifikan terhadap kualitas hasil audit. Hasil uji statistik menunjukan tingkat signifikan sebesar 0,025 yang berada dibawah atau lebih kecil dari nilai $a=0,05$ dengan koefisien regresi sebesar 0.083 yang artinya bahwa Ha4 diterima dan Ho4 ditolak. Berdasarkan hasil statistik deskriptif rata-rata aktual variabel kompetensi lebih besar dibandingkan dengan rata-rata teoitis yaitu 38,03 berbanding 30 . Hasil tersebut menunjukan bahwa auditor di Inspektorat Provinsi Bengkulu memiliki kompetensi yang sudah baik sehingga dalam menghasiilkan hasil audit yang berkualitas. Dengan demikian dapat disimpulkan hipotesis ke empat diterima.

\section{Pengaruh Pengalaman Kerja Terhadap Kualitas Hasil Audit}

Berdsarkan hasil penelitian menunjukkan bahwa pengalaman kerja berpengaruh positif yang signifikan terhadap kualitas hasil audit. Hasil uji statistik t pada variabel integritas memiliki nilai signifikan sebesar 0,001 yang berada dibawah atau lebih kecil dari nilai $a=0,05$ dengan nilai koefisien regresi sebesar 0,765 itu artinya bahwa Ha5 diterima dan Ho5 ditolak. Berdasarkan hasil statistik deskriptif rata-rata aktual variabel pengalaman kerja lebih besar dibandingkan dengan ratarata teoitis yaitu 34,66 berbanding 30. Hasil tersebut menunjukan bahwa auditor di Inspektorat Provinsi Bengkulu memiliki kompetensi yang sudah baik sehingga dalam menghasiilkan hasil audit yang berkualitas. Dengan demikian dapat disimpulkan hipotesis kelima diterima.

\section{Pengaruh Etika Auditor Terhadap Kualitas Hasil Audit}

Dari hasil pengolahan data dengan regresi berganda, diperoleh nilai signifikan sebesar 0,005 yang berada dibawah atau lebih kecil dari nilai $\alpha=0,05$ yang artinya bahwa Ha6 diterima dan Ho6 ditolak. Berdasarkan hasil statistik deskriptif rata-rata aktual variabel etika audit lebih besar dibandingkan dengan rata-rata teoitis yaitu 39,33 berbanding 39. Hasil tersebut menunjukan bahwa auditor di Inspektorat Provinsi Bengkulu Auditor telah memahami pentingnya suatu kode etik dan mematuhi kode etik tersebut sebagai etika auditor dan melaksanakan penugasan audit sesuai dengan ketentuan yang berlaku, sehingga menghasilkan audit yang berkualitas. Dengan demikian dapat disimpulkan hipotesis keenam diterima.

\section{KESIMPULAN DAN SARAN}

\section{Kesimpulan}

304 | Seftya Dwi Shinta; Analysis of factors affecting the... 
Hasil penelitian dapat diambil kesimpulan bahwa independensi, objektivitas, integritas, kompetensi, pengalaman kerja, etika auditor berpengaruh signifikan terhadap kualitas hasil audit di Insperktorat Provinsi Bengkulu.

\section{Saran}

Penelitian selanjutnya disarankan memperbanyak jumlah sampel penelitian dengan objek penelitian yang lebih luas dengan menggunakan beberapa Inspektorat provinsi di Indonesia dan melakukan pengujian lebih lanjut terhadap variabel dengan memasukkan variabel lain yang mempengaruhi kualitas audit seperti motivasi kerja dan akuntabilitas

\section{DAFTAR PUSTAKA}

Agoes, Sukrisno. 2012. Auditing- Petunjuk Praktis Pemeriksaan Akuntan Oleh Akuntan Publik. 1sted. Jakarta: Salemba Empat.

Alim, M.N., T. Hapsari, dan L. Purwanti. 2007. Pengaruh Kompetensidan Independensi terhadap Kualitas Audit dengan Etika Auditor sebagai Variabel Moderasi. Jurnal Simposium Nasional Akuntansi X. Makasar.

Ikatan Akuntan Indonesia. 2001. Standar Profesional Akuntan Publik. Jakarta: Salemba Empat.

Mulyadi. 2014. Auditing, Buku 1. Edisi 6, C. Jakarta: Salemba Empat.

Sukriah, Ika. Akram, Biana Adha Inapty. 2009. Pengaruh Pengalaman Kerja, Independensi, Objektivitas, Integritas, dan Kompetensi terhadap Kualitas Hasil Pemeriksaan. Jurnal Simposium Nasional Akuntansi XII. Palembang.

Suraida. 2005. Pengaruh Etika, Kompentensi, Pengalaman Auditor dan Resiko Audit Terhadap Skeptisme Profesional Auditor dan Ketepatan Pemberian Opini Akuntan Publik. Jurnal IImiah. Vol 7. No.3

Triandis,H.C. 1980.Value Attitudes and Interpersonal Behavior. University of Nabraska Press,Lincoln,NE,pp.175-259 